\title{
Cloud Point Extraction of Carbendazim Pesticide in Foods and Environmental Matrices Prior to Visible Spectrophotometric Determination
}

\author{
Zuhair A-A Khammas*, Suher Salah Ahmad \\ Department of Chemistry, College of Science for Women, University of Baghdad, Jadiyriah, Baghdad, Iraq \\ Email address: \\ saifkhammas@gmail.com(Z.A-A Khammas), suher_salah@yahoo.com (S. S. Ahmed) \\ ${ }^{*}$ Corresponding author
}

\section{To cite this article:}

Zuhair A-A Khammas, Suher Salah Ahmad. Cloud Point Extraction of Carbendazim Pesticide in Foods and Environmental Matrices Prior to Visible Spectrophotometric Determination. Science Journal of Analytical Chemistry. Vol. 4, No. 3, 2016, pp. 30-41.

doi: $10.11648 /$ j.sjac.20160403.13

Received: April 13, 2016; Accepted: April 22, 2016; Published: May 23, 2016

\begin{abstract}
Two simple eco-friendly methods are described for nano-determination of carbendazim (MBC) pesticide in real samples. These methods are based on oxidation of MBC pesticide with Fe (III) ions in acidic medium. The formed Fe(II) ions reacts with potassium ferricyanide to form blue colored product (method A) which can easily be extracted into nonionic surfactant solution of Triton X-114 at cloud point temperature (CPT) of $55^{\circ} \mathrm{C}$ and $\mathrm{MBC}$ determined spectrophotometrically at absorption maximum of $685 \mathrm{~nm}$ with apparent molar absorptivity of $2.07 \times 10^{4} \mathrm{~L} \mathrm{~mol}^{-1} \mathrm{~cm}^{-1}$. The Method B is based on the reaction of the formed $\mathrm{Fe}$ (II) with 2, 2'-bipyridyl to form a stable orange colored complex which can also be extracted by Triton X-114 at the same CPT and MBC determined spectrophotometrically at absorption maximum of $521 \mathrm{~nm}$ with apparent molar absorptivity of $1.83 \times 10^{4} \mathrm{~L} \mathrm{~mol}^{-1} \mathrm{~cm}^{-1}$. Optimization of the experimental parameters was described and interferences study also examined. Under the optimum conditions established, the calibration graphs for MBC were linear in the range of 0.5-13 and 1-20 $\mathrm{ng} \mathrm{mL} \mathrm{m}^{-1}$, giving the detection limits of 0.46 and $0.49 \mathrm{ng} \mathrm{mL}^{-1}$ with enrichment factors of 85.7 and 38.9 fold for method A and $\mathrm{B}$ respectively. The average percent recoveries in the real spiked samples were $(97.86 \pm 1.06 \%)$ and $(98.66 \pm 0.93 \%)$, giving a precision in terms of $\%$ RSD in the range of $1.25-2.97 \%$ and $0.37-1.42 \%$ for method A and B respectively. The proposed methods were applied to the determination of MBC in vegetables, orange, and water samples.
\end{abstract}

Keywords: Carbendazim, Vegetables and Waters, Cloud Point Extraction, Visible Spectrophotometry

\section{Introduction}

The use of pesticides is considered a double-edged sword; they are very useful and important in addressing a broad range of diseases caused by various harmful insects in the agricultural products, thereby enhancing food production. But, at the same time it pays inevitably toward pollution of various environmental components and, therefore, is hazardous to human and animal health. In this regard, the massive use and/or misuse of any pesticide may lead to environmental problems and several poisoning cases in human beings and other organisms. Carbendazim (MBC) chemically named by IUPAC as methyl benzimidazol-2-yl carbamate (Figure 1) is a benzimidazolic systemic fungicide widely used in agriculture for controlling several diseases on the fruits, vegetables, tobacco, cotton and cereals, and also used in post-harvest protection of crops against fungal diseases [1-2]. Carbendazim is degraded slowly in the environment because the nature of benzimidazolic ring in its structure difficult to break thus it persists for a long time in the environment [3].<smiles>COC(=O)Nc1nc2ccccc2[nH]1</smiles>

Figure 1. The structural formula of Carbendazim (chemical formula: $\mathrm{C}_{9} \mathrm{H}_{9} \mathrm{~N}_{3} \mathrm{O}_{2}$, mol.wt. $191.21 \mathrm{~g} \mathrm{~mol}^{-1}$ ).

In fact, this property makes this pesticide a very serious problem for the environment and has the direct detrimental 
effect on human and animal health, and on this basis it is listed in toxicity class IV pesticides [4]. Accordingly, different international legislations bodies such as the European Union (EU) [5], United States Environmental Protection Agency (US EPA) [6], World Health Organization (WHO) [7] and other international bodies have been established the maximum residues level (MRL) set for $\mathrm{MBC}$, for example, orange in the EU is set at $0.2 \mathrm{mg} / \mathrm{kg}$, cucumber in the $\mathrm{FAO} / \mathrm{WHO}$ set at 0.05 $\mathrm{mg} \mathrm{kg}^{-1}$, food in China set at $0.5 \mathrm{mg} / \mathrm{kg}$ [8] and a Brazilian regulatory agency, sets a limit of $0.02 \mathrm{mg} \mathrm{kg}^{-1}$ as the human acceptable daily intake (ADI) of MBC [9]. In light of this information, importance of continuous controlling and assessment for the presence of $\mathrm{MBC}$ residue at low levels in a variety of samples is a must and needs to establish sensitive, selective and reliable methods with high speed.

Several analytical techniques for MBC determination have been reported in chemical literature, but the most common one based on the sophisticated techniques, and on the particular the chromatographic methods including high-performance liquid chromatography (HPLC) [1, 10-12], high-performance liquid chromatography-mass spectrometry (HPLC-MS) [13-15], gas chromatography(GC) [16] and ion chromatography with fluorescence detector [17]. In addition, other techniques were also reported such electro-analytical methods [18-21], immunoassay [22], fluorescence spectrometry [23]. Since these methods have certainly high-sensitivity and low detection limit, but they are expensive, tedious and not available in most laboratories. UV-Visible spectrophotometric technique has a limited use in the determination of MBC due to the lack of its sensitivity and therefore, a scarce papers have been appeared in literature [24] Because, in general, the concentration of pesticides in different types of food and environmental samples is very low, a pre-concentration step to quantify these compounds is a must. A number of extraction procedures coupled with different instrumental techniques have recently developed for extraction and enrichment of MBC in a variety of samples including solid phase extraction [25-27], dispersive liquid-liquid microextraction [28-31], ionic liquid-dispersive liquid-liquid microextraction [32]. cloud point extraction (CPE) is now becoming a well-established and accepted as an alternative method of extraction / enrichment methodology of organic pollutants including pesticides in various matrices due to its simplicity, eco-friendly, cheap and relatively high extraction efficiency [33-37].

In this work, we present two spectrophotometric methods for the determination of MBC after cloud point extraction (CPE) in different samples for the first time. These methods are based on the oxidation of MBC with Fe (III) ions in acidic medium. The formed $\mathrm{Fe}$ (II) ions react with potassium ferricyanide to form blue colored product (method A) and with 2, 2'-bipyridyl to form a stable orange colored complex (method B). These two colored products can easily extract into nonionic surfactant solution of Triton X-114 and MBC determined spectrophotometrically at each respective absorption maximum.

\section{Materials and Methods}

\subsection{Apparatus}

All absorption spectra and absorbance measurements for MBC throughout this study were carried out by using a Shimadzu double-beam UV-Vis Spectrophotometer model UV-1800 (Kyoto, Japan) working at a wavelength of 190-1100 $\mathrm{nm}$, and equipped with 5-mm optical path cell. For the solution $\mathrm{pH}$ measurement, a portable $\mathrm{pH}$-meter microprocessor (HANNA, Germany) was used. The shaking water bath SW23 microprocessor with PID temperature control (JULABO GmbH, Germany) was employed during the course of CPE experiments.

\subsection{Reagents and Materials}

All materials and reagents used in this work with high purity and doubly distilled water used in the preparation of all solutions and for the final rinsing of glass wares. Carbendazim (MBC) (99.0\% purity,) was purchased from Accustandard $^{\circledR}$ (Connecticut, USA). A stock solution (100 $\mu \mathrm{g} \mathrm{mL}^{-1}$ ) of MBC was prepared by dissolving $10 \mathrm{mg}$ in 20 $\mathrm{mL}$ of $0.1 \mathrm{~N} \mathrm{HCl}$ in a $100 \mathrm{~mL}$ volumetric flask and diluted to mark with distilled water and kept in an amber bottle in the refrigerator. Triton X-114 (purity $>99.9 \%$ ), was purchased from AMRESCO LLC (Solon, USA). A 10\% (v/v) of Triton $\mathrm{X}-114$ was prepared by diluting $10 \mathrm{~mL}$ in $100 \mathrm{~mL}$ water. A $1 \times 10^{-3} \mathrm{M}$ of $\mathrm{FeCl}_{3}(99.9 \%, \mathrm{BDH})$ was prepared by dissolving $0.0162 \mathrm{~g}$ in $5 \mathrm{~mL}$ water and and diluted to mark in $100 \mathrm{~mL}$ volumetric flask. A $0.01 \mathrm{M}$ potassium ferricyanide $(99.0 \%$, Sigma-Aldrich) was prepared by dissolving $0.3292 \mathrm{~g}$ in $5 \mathrm{~mL}$ water and diluted to mark in $100 \mathrm{~mL}$ volumetric flask. A $1 \times 10^{-3} \mathrm{M}$ of 2, 2-Bipyridyl $(99.0 \%$, BDH) was prepared by dissolving $0.0156 \mathrm{~g}$ in $5 \mathrm{~mL}$ water and diluted to mark in 100 $\mathrm{mL}$ volumetric flask. Acetate buffer solutions were prepared from different volumes of $0.1 \mathrm{M}$ of acetic acid $(>99 \%$, Sigma-Aldrich) and 0.1 M sodium acetate (99.0\%, Merck).). Orthophosphoric acid (85\%, BDH) was prepared by appropriate dilution of concentrated acid with water. Sodium sulphate, sodium acetate and magnesium sulphate 6-hydrates were purchased from Riedel-deHaën AG (Germany). Acetonirile was obtained from BDH (England). Carbograph and an ion-ion exchange (PSA) were purchased from Sigma-Aldrich (USA) and Vertical Chromatography Co., Ltd. (Thailand) respectively.

\subsection{Recommended CPE Procedures}

\subsubsection{Method A}

Aliquots of $\mathrm{MBC}$ standard or sample solution ranging from $0.05-1.3 \mathrm{~mL}$ of $100 \mathrm{ng} \mathrm{mL}^{-1}$ which corresponding to $0.5-13 \mathrm{ng}$ $\mathrm{mL}^{-1}$ of MBC were transferred into a series of $10 \mathrm{~mL}$ centrifugal tubes. To each tube $0.4 \mathrm{~mL}$ of $1 \times 10^{-3} \mathrm{M} \mathrm{FeCl}_{3}$ solution, $0.4 \mathrm{~mL}$ of $0.01 \mathrm{M} \mathrm{K}_{3} \mathrm{Fe}(\mathrm{CN})_{6}$ solution and $1 \mathrm{~mL}$ of acetate buffer $(\mathrm{pH}=4)$ were added, then kept the solution on water bath at $60^{\circ} \mathrm{C}$ for $15 \mathrm{~min}$ and cooled thereafter. Then, 1.0 $\mathrm{mL}$ of $1 \mathrm{~N} \mathrm{H}_{3} \mathrm{PO}_{4}$ and $0.8 \mathrm{~mL}$ of $10 \%$ Triton $\mathrm{X}-114$ were added. The content of each tube was made up to $10 \mathrm{~mL}$ with water. 
All tubes were transferred into a water bath at $55^{\circ} \mathrm{C}$ for $15 \mathrm{~min}$ to induce the formation of cloudy solution and centrifuged at $3500 \mathrm{rpm}$ for $20 \mathrm{~min}$ to separate the two phases. After decantation of the aqueous phase, the surfactant-rich phase that remained adhered to the tube was dissolved with a $1.0 \mathrm{~mL}$ of ethanol: water (1:1) and the absorbance of each solution containing $\mathrm{MBC}$ was measured spectrophotometrically in 5 -mm quartz cell at $\lambda_{\max }$ of $685 \mathrm{~nm}$ against a reagent blank solution.

\subsubsection{Method B}

Aliquots of MBC standard or sample solution ranging from 0.1-2.0 mL of $100 \mathrm{ng} \mathrm{mL}{ }^{-1}$ which corresponding to $1-20 \mathrm{ng}$ $\mathrm{mL}^{-1} \mathrm{MBC}$ were transferred into a series of $10 \mathrm{~mL}$ centrifugal tubes. To each tube $0.8 \mathrm{~mL}$ of $1 \times 10^{-3} \mathrm{M} 2,2$-Bipyridyl solution, $0.8 \mathrm{~mL}$ of $1 \times 10^{-3} \mathrm{M} \mathrm{FeCl}_{3}$ solution and $1.0 \mathrm{~mL}$ of acetate buffer $(\mathrm{pH}=3)$ were added and kept on water bath at $50^{\circ} \mathrm{C}$ for $15 \mathrm{~min}$ and cooled thereafter. Then, $0.6 \mathrm{~mL}$ of $10 \%$ Triton $\mathrm{X}-114$ was added and the content of each tube diluted to 10 $\mathrm{mL}$. All tubes were transferred into a water bath at $60^{\circ} \mathrm{C}$ for 30 min to induce the formation of a cloudy solution and centrifuged at $3500 \mathrm{rpm}$ for $20 \mathrm{~min}$ to separate the two phases. After decantation of the aqueous phase, the surfactant-rich phase that remained adhered to the tube was dissolved with a $1.0 \mathrm{~mL}$ of ethanol: water $(1: 1)$ and the absorbance of each solution containing MBC was measured spectrophotometrically in $5-\mathrm{mm}$ quartz cell at $\lambda_{\max }$ of $521 \mathrm{~nm}$ against a reagent blank solution.

\subsection{Sample Preparation}

\subsubsection{Water}

About one liter of drinking and river water samples was randomly collected from the campus of University of Baghdad / Iraq. The river water was first filtered off to remove any suspended materials and all samples were kept in the refrigerator until analyzed. Each sample was spiked with different concentration of $\mathrm{MBC}$ standard and subjected to recommended $\mathrm{CPE}$ procedures $(\mathrm{A}$ and $\mathrm{B}$ ) and $\mathrm{MBC}$ was determined by spectrophotometry at $\lambda_{\max }$ of 685 and $521 \mathrm{~nm}$ respectively, from the constructed calibration curves.

\subsubsection{Soil}

The soil sample was randomly collected from the home garden and the soil sample solution was prepared according to the procedure adopted by Pourreza et al [31] with little modification. The sample was air-dried at room temperature, ground in agate mortar into small particle size of about 250 $\mu \mathrm{m}$ sieves and stored in a closed vessel. $20 \mathrm{~g}$ of sample was weighted in $100 \mathrm{~mL}$ conical flasks and $40 \mathrm{~mL}$ of $0.1 \mathrm{M} \mathrm{HCl}$ was added. The content was shaked in a mechanical shaker for one hr., then filtered and the $\mathrm{pH}$ of the filtered was adjusted to 7.0 by diluted $\mathrm{NaOH}$. Three portions of the resultant solution were directly spiked with different concentration of MBC standard solutions and subjected to recommend $\mathrm{CPE}$ procedures (A and $\mathrm{B}$ ) and $\mathrm{MBC}$ was determined by spectrophotometry at $\lambda_{\max }$ of 685 and $521 \mathrm{~nm}$ respectively from the constructed calibration curves.

\subsubsection{Vegetables and Orange}

Vegetables (Cucumber and Tomato) and an orange were purchased from local markets in Baghdad, Iraq. The QuEChERS (quick, easy, cheap, effective, rugged, and safe) method [38] used for pesticide residue analysis was adopted with little modification for sample preparation of vegetables and orange. A $0.5 \mathrm{~kg}$ of each sample was selected and the edible part was cut into $1-\mathrm{cm}$ pieces and blended using a commercial food mixer for homogenization of the sample. A $15 \mathrm{~g}$ sample portion was placed in $100 \mathrm{~mL}$ conical flask and $20 \mathrm{~mL}$ of solvent mixture containing acetic acid and acetonitrile (1:5) was added and the content was shaken vigorously in an electrical shaker for one hr. After shaking, the extract was withdrawn and transferred into $50 \mathrm{~mL}$ centrifugal tube and mixed with $10 \mathrm{~g}$ sodium sulphate, $4 \mathrm{~g}$ magnesium sulphate, $1 \mathrm{~g}$ of sodium acetate and centrifuged for $10 \mathrm{~min}$ at $250 \mathrm{rpm}$ to separate the phases. The upper layer was taken and mixed with $0.3 \mathrm{~g}$ PSA and $0.6 \mathrm{~g}$ Carbograph in another centrifugal tube and immediately shaked and filtered. The filtrate solution was evaporated at $50^{\circ} \mathrm{C}$ on water bath to remove the solvent. The residue was dissolved with water then diluted to $10 \mathrm{~mL}$ in standard volumetric flask. Each sample solution was spiked with different concentration of $\mathrm{MBC}$ standard solutions and subjected to recommend $\mathrm{CPE}$ procedures (A and $\mathrm{B}$ ) and $\mathrm{MBC}$ was determined by spectrophotometry at $\lambda_{\max }$ of 685 and $521 \mathrm{~nm}$ respectively from the constructed calibration curves.

\subsection{Statistical Analysis}

Excel 2007 (Microsoft Office ${ }^{\circledR}$ ) and Minitab version 17(Minitab Inc., State College, PA, USA) were employed to carry out all statistical calculations such as regression and correlation analysis, ANOVA and significance tests.

\section{Results and Discussion}

\subsection{Mechanism of Reactions}

It is undoubtedly proved that iron (III) salts can act as oxidants for most organic compounds in certain experimental conditions leading to the formation of oxidizing organic product and Fe (II) as reduced form of Fe (III) [39-41]. This idea has been utilized to design two analytical methods for the determination of $\mathrm{MBC}$ using the combined CPE-Spectrophotometry. To act as an oxidant, Fe (III) salt can reduce to $\mathrm{Fe}$ (II) salt which is equivalent to the amount of organic material [42]. The amount of iron (II) formed can then be determined spectrophotometrically by complexing with the familiar conventional reagents. Thus in method $\mathrm{A}, \mathrm{Fe}(\mathrm{II})$ ion is formed via the reduction of $\mathrm{Fe}(\mathrm{III})$ by MBC pesticide and subsequent reaction with potassium ferricyanide (PFC), forming a precipitate blue product (insoluble bright blue pigment called Turnbull's)which is soluble in acidic medium as shown in the Figure 2. 


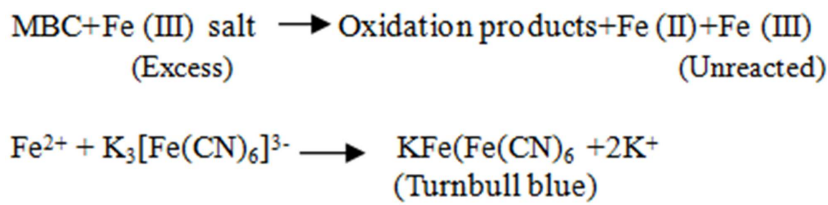

Figure 2. The reaction path of the method $A$.
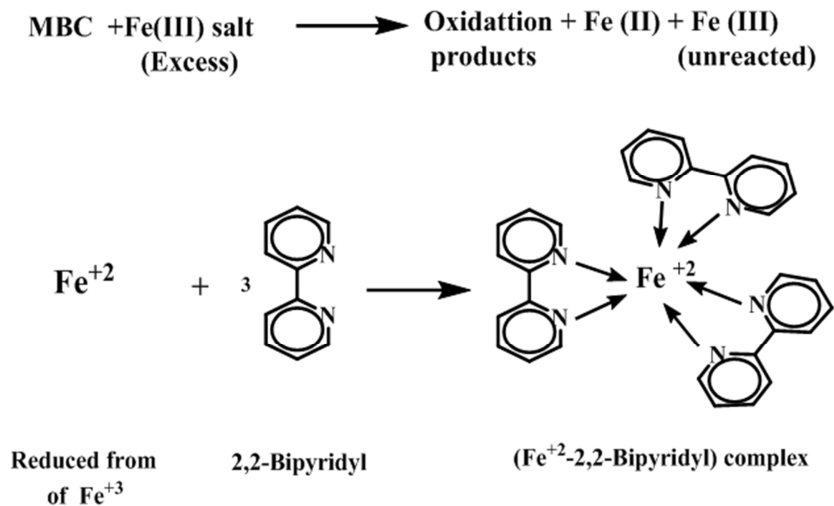

Figure 3. The reaction path of the method $B$.

Upon addition of $\mathrm{H}_{3} \mathrm{PO}_{4}$ and buffer solution $(\mathrm{pH}=3)$, the soluble colored product is formed which can be easily extracted into Triton X-114. Preliminary experiments have shown that the absorption maximum of the colored product at different concentration of $\mathrm{MBC}$ in micelle-mediating extraction occurs at $685 \mathrm{~nm}$ and the absorbance increases linearly with increasing the pesticide concentration. In Method B, the reduced form of Fe III (Fe II) can form a chelate with 2, 2'-bipyridyl (Figure 3 ) giving a stable orange colored complex exhibit absorption maximum at $521 \mathrm{~nm}$ in surfactant-rich phase against the reagent blank.

\subsection{Absorption Spectra}

The absorption spectra of the two colored products were recorded in the presence of surfactants against a reagent blank prepared under optimum conditions. The spectra of blue colored (method A) and orange product (method B) show the absorption maxima of 658 and $521 \mathrm{~nm}$ with molar absorptivities $(\varepsilon)$ of $2.07 \times 10^{4}$ and $1.83 \times 10^{4} \mathrm{~L} \mathrm{~mol}^{-1} \mathrm{~cm}^{-1}$ obtained respectively, while other reagents gave different absorption maxima in UV region as displayed in Figures 4 and 5. Thus, these absorption maxima of the colored products were adopted throughout this study.

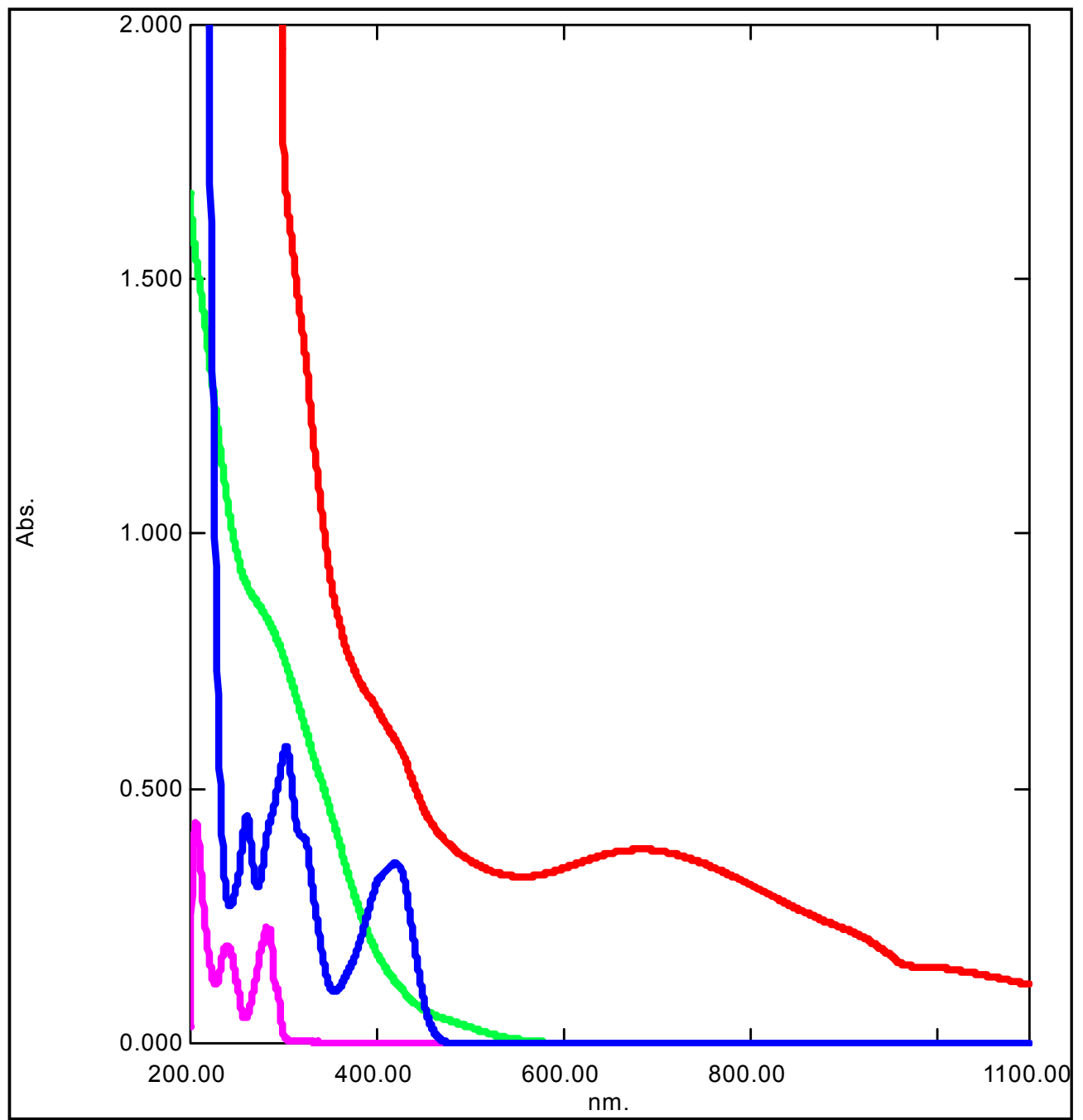

Figure 4. Absorption spectra of (a) Carbendazim solution(green color) (b) potassium ferric cyanide solution (blue color) (c) FeCl 3 solution(pink color) (d) Colored product in surfactant rich-phase (red color). 


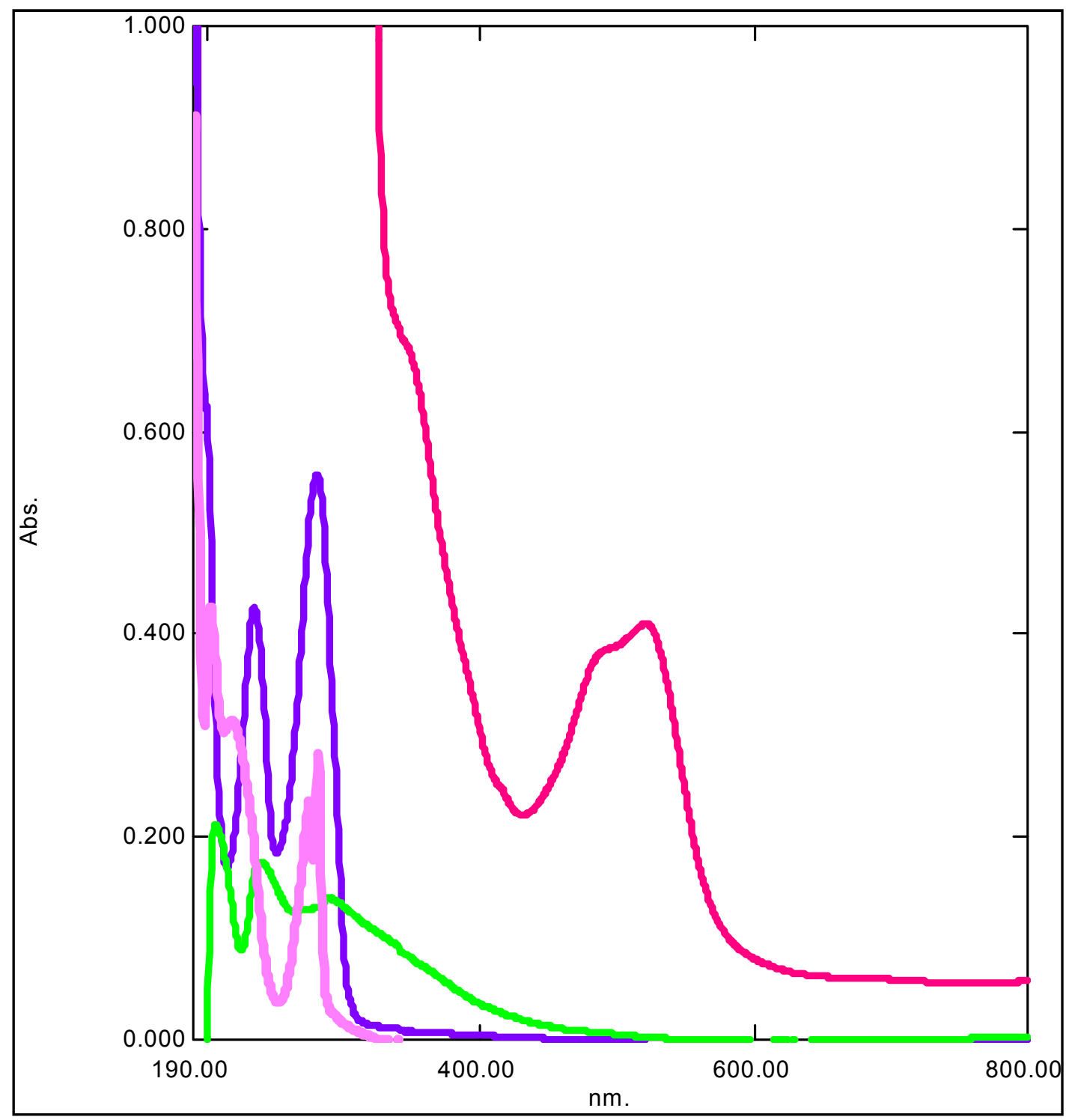

Figure 5. Absorption spectra of (a) Carbendazim solution (green color) (b) (c) 2,2'-bipyridyl(pink color) (c) FeCl 3 solution (purple color) (d) Colored product in surfactant rich-phase (red color).

\subsection{Optimization of CPE Procedure}

The influence of various parameters such as, $\mathrm{pH}, \mathrm{FeCl}_{3}$, $\mathrm{K}_{3} \mathrm{Fe}(\mathrm{CN})_{6}$ and 2,2'-bipyridyl concentration, $\mathrm{H}_{3} \mathrm{PO}_{4}$ concentration, Triton X-114 amount, equilibrium temperature and incubation time were investigated in detail by classical optimization to maximize the analytical figures of merit and the extraction efficiency of MBC.

\subsubsection{Effect of $p H$}

The solution $\mathrm{pH}$ is an important factor affecting the absorbance of the surfactant-rich phase (SRP) and thus the extraction efficiency of MBC for the two methods. Therefore, the $\mathrm{CPE}$ was carried out at temperature $70^{\circ} \mathrm{C}$ for $30 \mathrm{~min}$ in the solutions via varying the $\mathrm{pH}$ values within 2.0-7.0 at $\mathrm{MBC}$ concentration of $5 \mathrm{ng} \mathrm{ml}^{-1}$ (method A) and $12 \mathrm{ng} \mathrm{ml}^{-1}$ (method B) keeping other parameters such as $\mathrm{FeCl}_{3}, \mathrm{~K}_{3} \mathrm{Fe}(\mathrm{CN})_{6}, \mathrm{H}_{3} \mathrm{PO}_{4}$, 2,2'-bipyridyl and Trition X-114 at concentration of $1 \times 10^{-4} \mathrm{M}$, $1 \times 10^{-3} \mathrm{M}, 0.05 \mathrm{~N}, 1 \times 10^{-4} \mathrm{M}$ and $1 \%$ in final $10 \mathrm{~mL}$ aqueous solution respectively. The results are depicted in Figure 6. It can be noted that the absorbance at highest at $\mathrm{pH}$ of 4.0 for method A and 3.0 for method B, then decreased thereafter. Thus, these $\mathrm{pH}$ values were adopted in the further experiments.

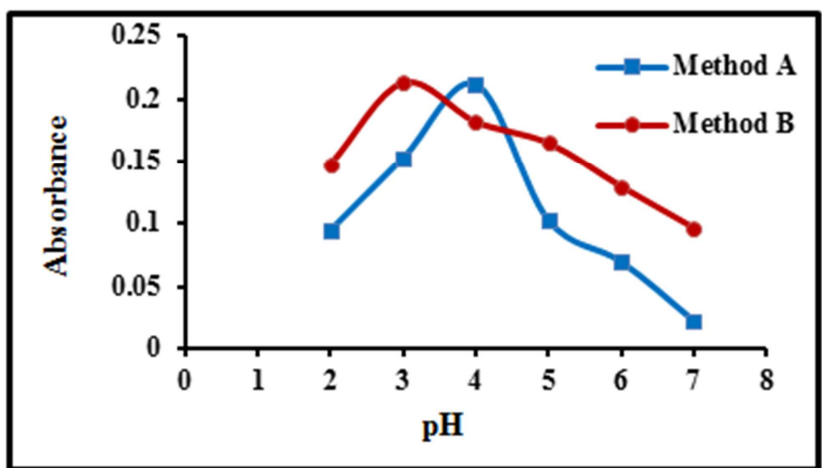

Figure 6. Effect of $p H$. 


\subsubsection{Effect of $\mathrm{FeCl}_{3}$ Concentration}

The influence of $\mathrm{FeCl}_{3}$ concentration on the formation of blue product and complex formation for the two methods was examined by varying the volume ranging from 0.1 to $1.2 \mathrm{~mL}$ of $1 \times 10^{-3} \mathrm{M} \mathrm{FeCl}_{3}$ solution at $\mathrm{pH} 4.0($ method $\mathrm{A})$ and 3.0 (method B), keeping other parameters constant. The results displayed in Figure 7 revealed that maximum absorbance was achieved when $\mathrm{FeCl}_{3}$ concentration was of $4 \times 10^{-5} \mathrm{M}(0.4 \mathrm{~mL}$ of $1 \times 10^{-3} \mathrm{M}$ in $10 \mathrm{~mL}$ final aqueous solution) for method $\mathrm{A}$ and $8 \times 10^{-5} \mathrm{M}\left(0.8 \mathrm{~mL}\right.$ of $1 \times 10^{-3} \mathrm{M}$ in $10 \mathrm{~mL}$ final aqueous solution) for method B. Consequently, these concentrations were selected as optimal for the next experiments.

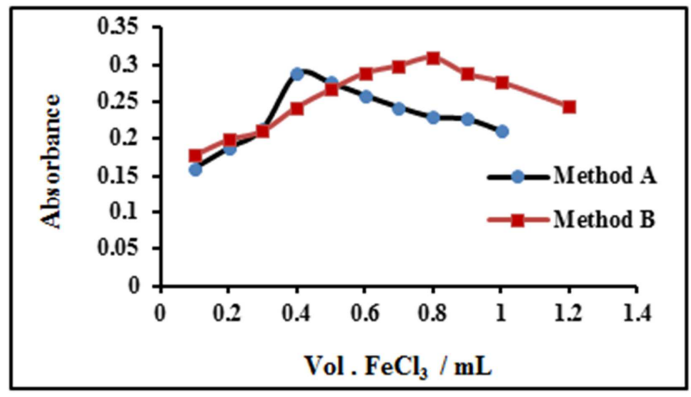

Figure 7. Effect of $\mathrm{FeCl}_{3}$ concentration [Conditions: method $\mathrm{A}: 5 \mathrm{ng} \mathrm{mL}^{-1}$

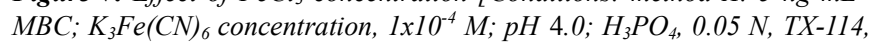
1\%; method B: $12 \mathrm{ng} \mathrm{mL}^{-1} \mathrm{MBC}$; 2,2'-bipyridyl, $1 \times 10^{-4} \mathrm{M} ; \mathrm{pH}, 3.0 ; \mathrm{TX}-114$, $1 \%$; equilibration temperature and incubation temperature, $70^{\circ} \mathrm{C}$ for $30 \mathrm{~min}$ for two method].

\subsubsection{Effect of Reagent Concentration}

The effect of $\mathrm{K}_{3} \mathrm{Fe}(\mathrm{CN})_{6}$ and 2,2'-bipyridyl reagents concentration on the absorbance signal of $\mathrm{MBC}$ was seeking by varying the volume from $0.1-1.0 \mathrm{~mL}$ of $1 \times 10^{-3} \mathrm{M}$ of both reagents. The results shown in Figure 8 appeared that the absorbance was linearly increased with increasing the reagents concentration and reached maximum at $4 \times 10^{-5} \mathrm{M}(0.4$ $\mathrm{mL}$ of $1 \times 10^{-3}$ in $10 \mathrm{~mL}$ solution) $\mathrm{K}_{3} \mathrm{Fe}(\mathrm{CN})_{6}$ and $8 \times 10^{-5} \mathrm{M}(0.8$ $\mathrm{mL}$ of $1 \times 10^{-3}$ in $10 \mathrm{~mL}$ solution) 2,2'-bipyridyl concentration. Therefore, these concentrations found to be a highly suitable for the formation of the resultant colored product and complex and thus it was adopted for further experiments as optimal.

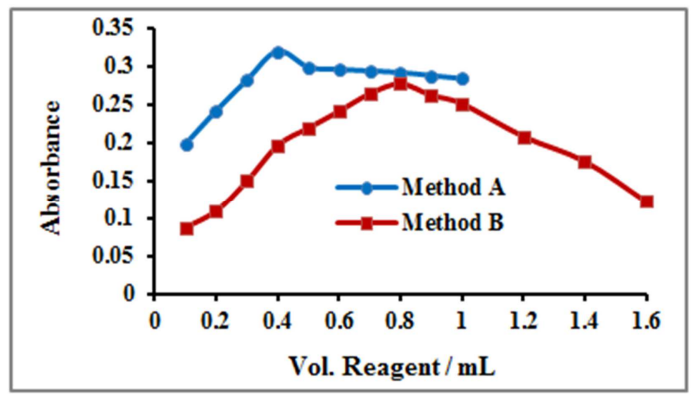

Figure 8. Effect of $\mathrm{K}_{3} \mathrm{Fe}(\mathrm{CN})_{6}$ and 2,2'-bipyridyl reagents concentration

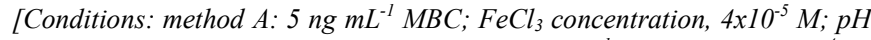
3.0; $\mathrm{H}_{3} \mathrm{PO}_{4}, 0.05 \mathrm{~N}, \mathrm{TX}-114,1 \%$; method $\mathrm{B}: 12 \mathrm{ng} \mathrm{mL} \mathrm{L}^{-1} \mathrm{MBC} ; \mathrm{FeCl}_{3}, 8 \times 10^{-4} \mathrm{M}$; $\mathrm{pH}, 4.0 ; \mathrm{TX}-114,1 \%$; equilibration temperature and incubation temperature, $70^{\circ} \mathrm{C}$ for $30 \mathrm{~min}$ for two method].

\subsubsection{Effect of $\mathrm{H}_{3} \mathrm{PO}_{4}$ Concentration}

It was observed that Turnbull's blue product formed before extraction in method A is a slightly soluble in the surfactant medium used and the extraction efficiency of MBC was very poor. One of previous studies[31] have shown that the presence phosphoric acid enhances the solubility of the blue product before the extraction process. For this, the effect of different concentrations of $\mathrm{H}_{3} \mathrm{PO}_{4}$ was conducted by varying the volume from 0.2-2.0 mL of $1.0 \mathrm{~N} \mathrm{H}_{3} \mathrm{PO}_{4}$ on the absorbance of the colored product. It can be seen (Figure 9) that the optimum concentration of $\mathrm{H}_{3} \mathrm{PO}_{4}$ was of $0.1 \mathrm{~N}$ in the final aqueous solution and thus it was selected in following experiments.

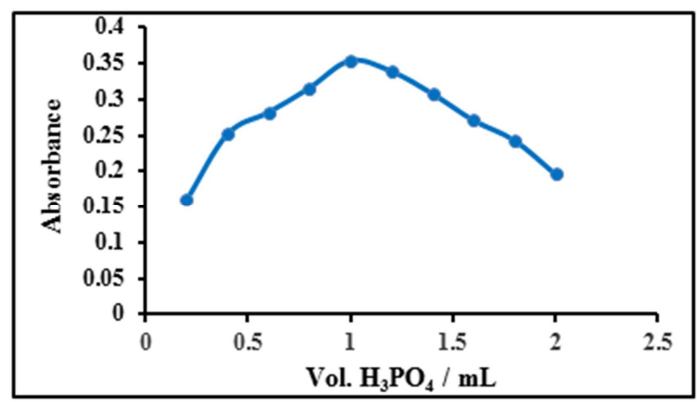

Figure 9. Effect of $\mathrm{H}_{3} \mathrm{PO}_{4}$ concentration [Conditions: method $\mathrm{A}: 5 \mathrm{ng} \mathrm{mL}^{-1}$ $\mathrm{MBC} ; \mathrm{FeCl}_{3}$ concentration, $4 \times 10^{-5} \mathrm{M} ; \mathrm{K}_{3} \mathrm{Fe}(\mathrm{CN})_{6}$ concentration, $4 \times 10^{-5} \mathrm{M}$; pH 3.0; TX-114, 1\%; equilibration temperature and incubation temperature, $70^{\circ} \mathrm{C}$ for $\left.30 \mathrm{~min}\right]$

\subsubsection{Effect of Surfactant Amount}

The variation of the absorbance with surfactant (Triton $\mathrm{X}-114$ ) amount on the extraction of MBC pesticide was studied within the volume range $0.1-1.0 \mathrm{~mL}$ of $10 \%$ Triton $\mathrm{X}-114$. As shown in Figure 10, at a lower amount of surfactant, the absorbance was low for the two methods and maximum remarkable extraction was observed for Triton X-114 amount of $0.8 \%$ for the method $\mathrm{A}$ and $0.6 \%$ for method $\mathrm{B}$ in the final $10 \mathrm{~mL}$ aqueous solution which gave the best preconcentration factor. Therefore, these values were adopted in the recommended CPE procedure.

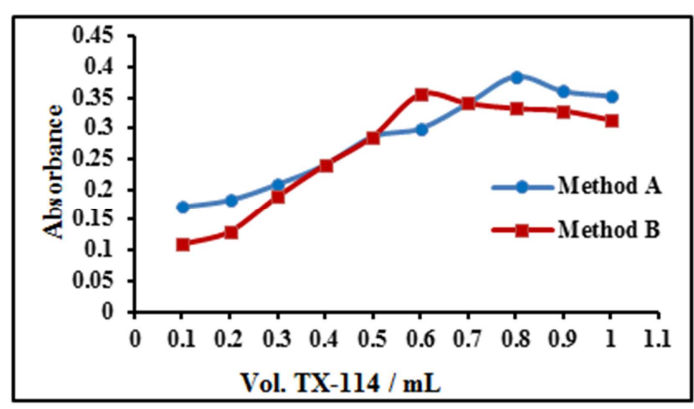

Figure 10. Effect of Triton X-114 amount [Conditions: method A: $5 \mathrm{ng} \mathrm{mL}^{-1}$ $\mathrm{MBC} ; \mathrm{FeCl}_{3}$ concentration, $4 \times 10^{-5} \mathrm{M} ; \mathrm{K}_{3} \mathrm{Fe}(\mathrm{CN})_{6}$ concentration, $4 \times 10^{-5} \mathrm{M} ; \mathrm{pH}$ 3.0; $0 . \mathrm{H}_{3} \mathrm{PO}_{4}, 0.1 \mathrm{~N}$; method $\mathrm{B}: 12 \mathrm{ng} \mathrm{mL} \mathrm{L}^{-1} \mathrm{MBC}$; $\mathrm{FeCl}_{3}$ concentration, $8 \times 10^{-4} \mathrm{M} ; 2,2^{\prime}$-bipyridyl concentration, $8 \times 10^{-4} \mathrm{M} ; \mathrm{pH}$, 4.0; equilibration temperature and incubation temperature, $70^{\circ} \mathrm{C}$ for 30 min for two method].

\subsubsection{Effect of Temperature and Time}

These two parameters play an important role in the CPE process for completion of the reaction and to achieve the best extraction of the target analyte. Thus the effect of equilibrium temperature and incubation time was varied in the range of 
$20-75^{\circ} \mathrm{C}$ and 5-50 min respectively as showed in Figures 9 and 10. It was found (Figure 11) that the maximum absorbance was obtained at $55^{\circ} \mathrm{C}$ for $15 \mathrm{~min}$ and $60^{\circ} \mathrm{C}$ for $30 \mathrm{~min}$ for the method $\mathrm{A}$ and $\mathrm{B}$ respectively, and they were nearly constant above these values. Accordingly, $55^{\circ} \mathrm{C}$ and $60^{\circ} \mathrm{C}$ were used in the recommended CPE procedure. The study of incubation time (Figure 12) also indicated that the maximum absorbance value was achieved at 15 and 30 min for the method $A$ and $B$ respectively. Thus, they were used as an optimal in the recommended CPE procedure.

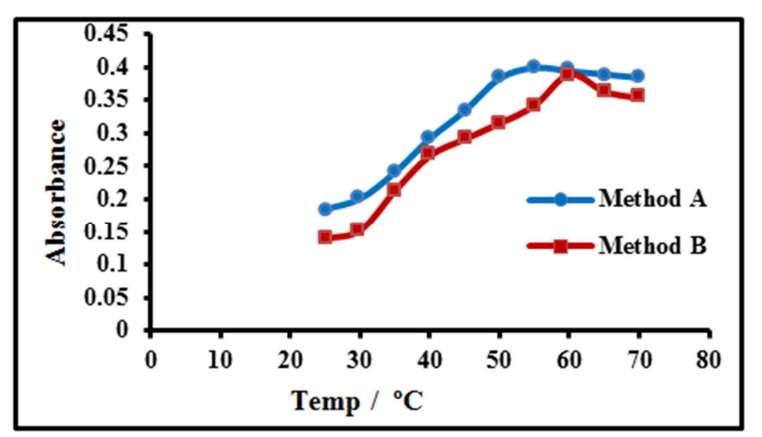

Figure 11. Effect of Temperature [Conditions: method A: $5 \mathrm{ng} m L^{-1} \mathrm{MBC}$; $\mathrm{FeCl}_{3}$ concentration, $4 \times 10^{-5} \mathrm{M} ; \mathrm{K}_{3} \mathrm{Fe}(\mathrm{CN})_{6}$ concentration, $4 \times 10^{-5} \mathrm{M} ; \mathrm{pH} \mathrm{3.0;}$

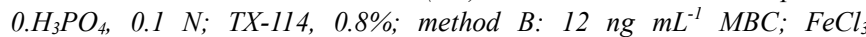
concentration, $8 \times 10^{-4} \mathrm{M} ; 2,2^{\prime}$-bipyridyl concentration, $8 \times 10^{-4} \mathrm{M}$; $\mathrm{pH}$, 4.0; TX-114, 0.6\%; incubation time, 30 min for two method].

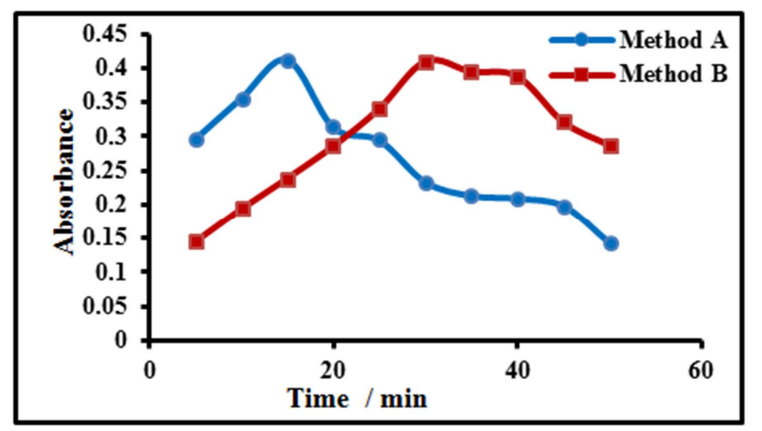

Figure 12. Effect of incubation time [Conditions: method A: $5 \mathrm{ng} \mathrm{mL}^{-1} \mathrm{MBC}$; $\mathrm{FeCl}_{3}$ concentration, $4 \times 10^{-5} \mathrm{M} ; \mathrm{K}_{3} \mathrm{Fe}(\mathrm{CN})_{6}$ concentration, $4 \times 10^{-5} \mathrm{M} ; \mathrm{pH} 3.0$; $0 . \mathrm{H}_{3} \mathrm{PO}_{4}, 0.1 \mathrm{~N} ; \mathrm{TX}-114,0.8 \%$; method $\mathrm{B}: 12 \mathrm{ng} \mathrm{mL}^{-1} \mathrm{MBC} ; \mathrm{FeCl}_{3}$ concentration, $8 \times 10^{-4} \mathrm{M} ; 2,2^{\prime}$-bipyridyl concentration, $8 \times 10^{-4} \mathrm{M} ; \mathrm{pH}, 4.0$; $T X-114,0.6 \%$; equilibration temperature, $55^{\circ} \mathrm{C}$ and $60^{\circ} \mathrm{C}$ for method $A$ and $B$ respectively].

\subsection{Order of Additions}

The effect of order for additions on the absorption signal of the colored product and the complex was also investigated. Table 1 reveals that the best order of addition was number 2 and 3 for the method A and B respectively, due to give a highest absorption signal among the others.

\subsection{Analytical Figures of Merit}

A series of standard solutions containing different MBC concentration was subjected according to the recommended $\mathrm{CPE}$ procedures $\mathrm{A}$ and $\mathrm{B}$, in order to construct the calibration graphs between the absorbance and MBC concentration as showed in Figures 13 and 14. The statistical data and analytical figures of merits for MBC in the two proposed CPESpectrophotometry are summarized in Table 2. The calibration graphs were linear in the range of 0.5-13 and 1-20 $\mathrm{ng} \mathrm{mL} \mathrm{m}^{-1}$ of MBC with the correlation coefficient of 0.9995 and 0.9997 for method A and B respectively. The percent linearity of $99.89 \%$ and $99.94 \%$ of the two methods suggest that the calibration curves are statically valid fit. These two fitted linear calibration models were used to estimate MBC concentration in all analysed samples which appear justified, on the statistical basis. The limit of detection and limit of quantitation are calculated using the following formulas; $\mathrm{LOD}=3 \sigma_{\mathrm{B}} / \mathrm{s} ; \quad \mathrm{LOQ}=10 \quad \sigma_{\mathrm{B}} / \mathrm{s}$, where $\left(\sigma_{\mathrm{B}}\right)$ is the standard deviation of the regression line and (s) its slope, and found to be of 0.46 and $0.49 \mathrm{ng} \mathrm{mL}{ }^{-1}$ for the method A and B respectively. The enrichment factor, defined as the ratio of slope of calibration curve obtained by CPE to that obtained without pre-concentration was of 85.7 and 38.9 fold for the method A and B respectively. This in turn enhanced the sensitivity of the spectrophotometric method which was 4.5 times better than that obtained by Naidu et al [24].

Concerning the detection limit, our finding was better than that obtained by other reported methods (Table 3). By considering a limit of detection of $0.46-0.49 \mu \mathrm{g} \mathrm{L}^{-1}$ in aqueous solution and $15 \mathrm{~g}$ of vegetable and fruit samples in $10 \mathrm{~mL}$ solution, LOD of the method was also calculated and found in the range $0.0031-0.0032 \mathrm{mg} \mathrm{kg}^{-1}$ for MBC. This finding has encouraged the authors to apply the proposed methods in the estimation of $\mathrm{MBC}$ in real samples such as vegetables, fruits and environmental samples to test its applicability and reliability. In fact, the developed methods comply with the requirements of the international standards in terms of the maximum residue limits (MRL) of $\mathrm{MBC}$ insecticide in different types of foods set by $\mathrm{FAO} / \mathrm{WHO}$ and other international bodies [7-8].

\subsection{Accuracy and Precision}

The accuracy and precision are the most crucial and basic requirements in method validation for ensuring quality and reliability of the results in the applicability of the analytical method. Thus, the accuracy of the proposed methods was examined in terms of percent recovery by the spiking river and soil samples with 1.0, 5.0 and $11.0 \mathrm{ng} \mathrm{mL}^{-1}$ standard MBC for method A and 2.0, 8.0 and 16.0 $\mathrm{ng} \mathrm{mL}^{-1}$ standards BDC for method B, from which subjected to the recommended CPE procedures. The results are presented in Tables 4 and 5. It can be seen that a good accuracy in terms of percent recoveries obtained were within average of $97.86 \pm 1.06 \%$ for Method A and $98.66 \pm 0.93 \%$ for method B. This confirmed that the systematic errors are relatively absent, concluding the presence of matrix components of these samples have no appreciable effect on the determination of the target analyte. Also, each spiked sample was repeated five times for precision testing in terms of repeatability and found in the range of $1.25-2.97 \%$-for method A and $0.37-1.42 \%$ for method B, indicative of a good precise for the proposed method. So, these analytical procedures may be very useful and suitable for the application in the routine environmental and food laboratories. 


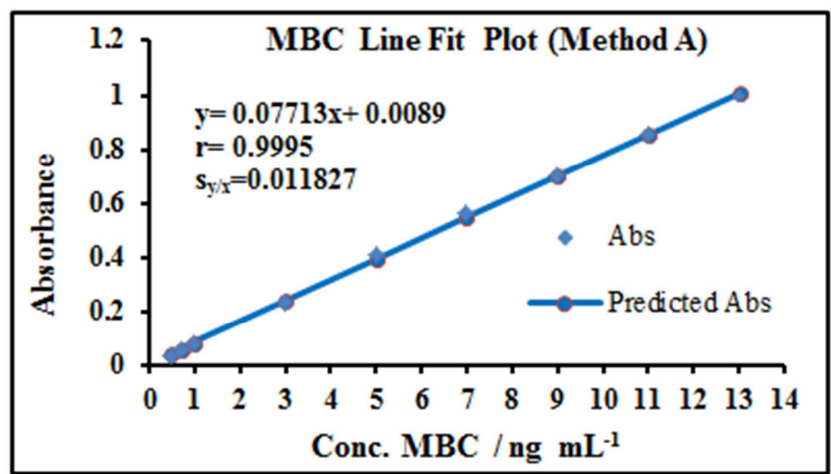

Figure 13. Calibration curve of $M B C$ pesticide for the proposed method A.

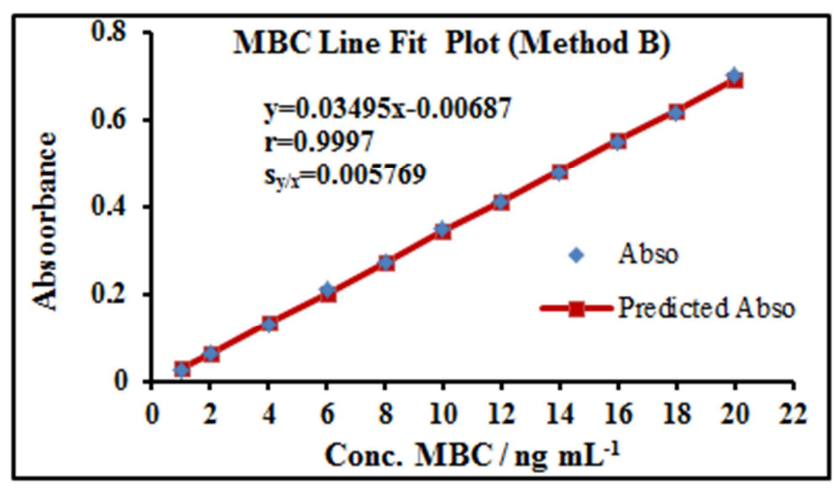

Figure 14. Calibration curve of MBC pesticide for the proposed method B.

Table 1. Effect of order of additions.

\begin{tabular}{llll}
\hline Method & No. & Addition & Abs \\
\hline & 1 & $\mathrm{MBC}+\mathrm{H}_{3} \mathrm{PO}_{4}+\mathrm{K}_{3} \mathrm{Fe}(\mathrm{CN})_{6}+\mathrm{FeCl}+\mathrm{Buffer}(4)+\mathrm{TX}-114$ & 0.329 \\
$\mathrm{~A}$ & 2 & $\mathrm{MBC}+\mathrm{FeCl}_{3}+\mathrm{K}_{3} \mathrm{Fe}(\mathrm{CN})_{6}+\mathrm{Buffer}(4)+\mathrm{H}_{3} \mathrm{PO}_{4}+\mathrm{TX}-114$ & 0.412 \\
& 3 & $\mathrm{MBC}+\mathrm{K}_{3} \mathrm{Fe}(\mathrm{CN})_{6}+\mathrm{FeCl}_{3}+\mathrm{Buffer}(4)+\mathrm{H}_{3} \mathrm{PO}_{4}+\mathrm{TX}-114$ & 0.368 \\
& 4 & $\mathrm{MBC}+\mathrm{Buffer}(4)+\mathrm{FeCl}_{3}+\mathrm{K}_{3} \mathrm{Fe}(\mathrm{CN})_{6}+\mathrm{H}_{3} \mathrm{PO}_{4}+\mathrm{TX}-114$ & 0.298 \\
& 1 & $\mathrm{MBC}+\mathrm{FeCl}_{3}+2,2-\mathrm{Bipyridyl}_{\mathrm{Buffe}(3)+\mathrm{TX}-114}$ & 0.241 \\
$\mathrm{~B}$ & 2 & $\mathrm{MBC}+\mathrm{Buffer}(3)+\mathrm{FeCl}_{3}+2,2-\mathrm{Bipyridyl}+\mathrm{TX}-114$ & 0.311 \\
& 3 & $\mathrm{MBC}+2,2-\mathrm{Bipyridyl}+\mathrm{FeCl}_{3}+\mathrm{Buffer}(3)-+\mathrm{Tritonx}-114$ & 0.410 \\
& 4 & $\mathrm{MBC}+\mathrm{Buffer}(3)+\mathrm{FeCl}_{3}+2,2-\mathrm{Bipyridyl}+\mathrm{TX}-114$ & 0.193 \\
\hline
\end{tabular}

Table 2. The statistical data and analytical figures of merits for carbendazim by CPE-Spectrophotometry.

\begin{tabular}{|c|c|c|}
\hline Parameter & Method A & Method B \\
\hline color & Blue & Orange \\
\hline$\lambda_{\max }(\mathrm{nm})$ & 685 & 521 \\
\hline Regression equation & $y=0.07713 x+0.0089$ & $y=0.02395 x-0.00687$ \\
\hline Standard deviation of regession line $\left(\mathrm{S}_{\mathrm{y} / \mathrm{x}}\right)$ & 0.011827 & 0.005769 \\
\hline Correlation coefficient(r) & 0.9995 & 0.9997 \\
\hline Linearity percentage (\%R) & 99.89 & 99.94 \\
\hline C.L. for the slope $\left(b \pm t_{\mathrm{b}}\right)$ at $95 \%$ & $0.07713 \pm 0.0021$ & $0.02395 \pm 0.00063$ \\
\hline C.L. for the intercept $\left(a \pm t_{a}\right)$ at $95 \%$ & $0.0089 \pm 0.01501$ & $-0.00687 \pm 0.00753$ \\
\hline Beer's law range $\left(\mathrm{ng} \mathrm{mL} \mathrm{mL}^{-1}\right)$ & $0.5-13$ & $1-20$ \\
\hline Limit of Detection (ng $\left.\mathrm{mL}^{-1}\right)$ & 0.46 & 0.49 \\
\hline Limit of Quantitation $\left(\mathrm{ng} \mathrm{mL}^{-1}\right)$ & 1.53 & 1.65 \\
\hline Sandell's sensitivity $\left(\mu \mathrm{g} \mathrm{cm}^{-2}\right)$ & 0.013 & 0.029 \\
\hline Molar absorptivity $\left(\mathrm{L} \cdot \mathrm{mol}^{-1} \cdot \mathrm{cm}^{-1}\right)$ & $2.07 \times 10^{4}$ & $1.83 \times 10^{4}$ \\
\hline $\mathrm{RSD} \%(\mathrm{n}=5)$ & 2.15 at $1 \mathrm{ng} \mathrm{mL}^{-1}$ & 3.25 at $4 \mathrm{ng} \mathrm{mL}^{-1}$ \\
\hline $\mathrm{RSD} \%(\mathrm{n}=5)$ & 1.64 at $9 \mathrm{ng} \mathrm{mL}^{-1}$ & 2.74 at $16 \mathrm{ng} \mathrm{mL}^{-1}$ \\
\hline Preconcentration factor* & 50 & 58.8 \\
\hline Enrichment factor & 85.7 & 38.9 \\
\hline Extraction efficiency $(\% \mathrm{E})^{* *}$ & 98.2 & 98.0 \\
\hline
\end{tabular}

*Preconcentration factor was calculated the ratio of the original sample volume to that of extracted volume (of surfactant-rich phase)** Extraction efficiency was calculated according to the following formula,

$\% E=[(1-C w \mid(R v+1) C S R P] x 100$

where $R_{v}$ is the volume ratio of surfactant-rich phase(SRP) to the aqueous phase. $C_{w}$ is the concentration of analyte in aqueous phase (original solution before $\mathrm{CPE}$ ), and $\mathrm{C}_{\mathrm{SRP}}$ is the concentration of target analyte in SRP, which was quantified using calibration curve obtained from the original solutions (without $\mathrm{CPE}$ ).

Table 3. Comparison of the proposed methods with other reported methods for the determination of MBC.

\begin{tabular}{lllll}
\hline Extraction Procedure & Detection System & Linear Range $\left(\mathbf{n g} \mathbf{~ m L}^{-\mathbf{1}}\right)$ & Limit of Detection $\left(\mathbf{n g} \mathbf{~ m L}^{-\mathbf{1}}\right)$ & Ref. \\
\hline SPE & HPLC & $25-500$ & 3.55 & {$[27]$} \\
SPE & HPLC & - & 20 & {$[29]$} \\
SPME & HPLC & $10-1000$ & 1.0 & {$[30]$} \\
DLLME & HPLC & $5-800$ & 0.5 & {$[31]$} \\
DLLME & UV-Vis & $5-600$ & 2.1 & {$[32]$} \\
IL-DLLME & HPLC & $5-500$ & 5 & {$[33]$} \\
CPE & UV-Vis & $0.5-13$ & 0.46 & This \\
& & $1.0-20$ & 0.49 & work \\
\hline
\end{tabular}


Table 4. The accuracy and precision of the proposed method (A) for the determination of MBC by CPE-Spectrophotometry.

\begin{tabular}{|c|c|c|c|c|c|c|}
\hline sample & $\begin{array}{l}\text { Amount MBC taken } \\
\left(\mathrm{ng} \mathrm{mL} \mathbf{~}^{-1}\right)\end{array}$ & $\begin{array}{l}\text { Amount MBC found } \\
\left(\mathrm{ng} \mathrm{mL}^{-1}\right)\end{array}$ & $\operatorname{Rec}(\%)$ & $\begin{array}{l}\text { Ave. Recovery (\%) } \\
(x \pm t s / \sqrt{n})\end{array}$ & $\mathbf{E}_{\text {rel }}(\%)$ & $\% \operatorname{RSD}(n=5)$ \\
\hline \multirow{3}{*}{ River Water } & 1 & 0.98 & 98.00 & \multirow[t]{6}{*}{$97.86 \pm 1.06 \%$} & -2.00 & 2.31 \\
\hline & 5 & 4.88 & 97.60 & & -2.40 & 1.93 \\
\hline & 11 & 10.85 & 98.64 & & -1.36 & 1.25 \\
\hline \multirow{3}{*}{ Soil } & 1 & 0.96 & 96.0 & & -4.0 & 2.97 \\
\hline & 5 & 4.94 & 98.8 & & -1.2 & 2.10 \\
\hline & 11 & 10.79 & 98.1 & & -1.9 & 1.77 \\
\hline
\end{tabular}

Table 5. The accuracy and precision of the proposed method (B) for the determination of MBC by CPE-Spectrophotometry.

\begin{tabular}{|c|c|c|c|c|c|c|}
\hline sample & $\begin{array}{l}\text { Amount MBC taken } \\
\left(\mathrm{ng} \mathrm{mL^{-1 } )}\right.\end{array}$ & $\begin{array}{l}\text { Amount MBC found } \\
\left(\mathrm{ng} \mathrm{mL} \mathbf{~}^{-1}\right)\end{array}$ & $\begin{array}{l}\operatorname{Rec} \\
(\%)\end{array}$ & $\begin{array}{l}\text { Ave. Recovery } \\
(\%) \text { at } 95 \% \text { C.I } \\
(x \pm t s / \sqrt{n})\end{array}$ & $\begin{array}{l}\mathbf{E}_{\text {rel }} \\
(\%)\end{array}$ & $\begin{array}{l}\% R S D \\
(n=5)\end{array}$ \\
\hline \multirow{3}{*}{ River Water } & 2 & 1.98 & 99.00 & \multirow[t]{5}{*}{$98.66 \pm 0.93 \%$} & -1.00 & 1.42 \\
\hline & 8 & 7.95 & 99.38 & & -0.62 & 1.09 \\
\hline & 16 & 15.89 & 99.32 & & -0.68 & 0.73 \\
\hline \multirow[b]{2}{*}{ Soil } & 2 & 1.94 & 97.00 & & -3.0 & 1.01 \\
\hline & 8 & 7.87 & 98.38 & & -1.62 & 0.86 \\
\hline
\end{tabular}

\subsection{Interferences Study}

The study was conducted by addition of various amounts of expected interfering species in the samples under study to the standard solution containing $10 \mathrm{ng} \mathrm{mL}^{-1}$ of $\mathrm{MBC}$ followed the general CPE procedure (A) and (B), to verify more whether these interfering species affect the accuracy of the proposed methods. The results are shown in Tables 6 and 7. The results revealed that the metal ions and other compound species at different amounts do not effect on the percent recovery levels of each pesticide, indicating no appreciable interferences exist, affect the determination of $\mathrm{MBC}$ pesticide and concluding that good selectivity has achieved for the proposed methods.

\subsection{Applications}

According to the initial analysis of the study samples, it was shown that there is no existence of any residues of MBC can be detected in these samples by the proposed methods. Therefore, all the selected samples were spiked with MBC standard at concentration level of 3.0, 7.0 and $13.0 \mathrm{ng} \mathrm{mL}^{-1}$ for method $\mathrm{A}$ and 4.0, 10.0 and $18.0 \mathrm{ng} \mathrm{mL}^{-1}$ for method $\mathrm{B}$, and then subjected to the recommended CPE procedure for five replicates measurements and the target $\mathrm{MBC}$ concentration in each spiked sample was measured spectrophotometrically at each respective absorption maximum. The results are summarized in Tables 8 and 9. In all cases, it can be seen that the percent recovery levels for MBC pesticide in all sample were acceptable and ranging from $95.00 \%$ to $100.14 \%$ with standard deviation from 0.97 to 2.49 for method A and from $96.50 \%$ to $100.50 \%$ with standard deviation from 0.71 to 2.49 for method B.

The results of the two methods were also subjected to statistical treatment by using t-test at $95 \%$ confidence interval to test the significant of the two methods by using t-test: two-sample assuming equal variances as showed in Table 10. It can be seen that the calculated t-value $[|t|(=1.17285)]$ tested whether at one-tail or two-tail at $\mathrm{P}(\mathrm{T}<=\mathrm{t})=0.05$ for 22 degrees of freedom is less than the critical values, so the null hypothesis (Ho) is retained, concluding there is no evidence to suggest that the method $\mathrm{A}$ is significantly difference from Method B in accuracy ( $\mathrm{p}=0.13, \mathrm{p}=0.25)$. Also, F-test has shown that the calculated $\mathrm{F}$-value $(\mathrm{F}=1.288)$ whether at one-tail or two-tail at $\mathrm{P}(\mathrm{T}<=\mathrm{t})=0.05$ for 11 degrees of freedom is less than the critical values $\left(\mathrm{F}_{0.05,11,11}=2.81\right.$ one-tail $)$, so the null hypothesis (Ho) is accepted, concluding that there appears no statistical evidence to suggest that the variability of the two methods is significantly different in the precision $(\mathrm{p}=0.34)$.

Table 6. Effect of diver's species on the percent recovery of $M B C$ by the proposed method A.

\begin{tabular}{|c|c|c|c|c|}
\hline \multirow{2}{*}{$\begin{array}{l}\text { Foreign } \\
\text { species }\end{array}$} & \multicolumn{3}{|c|}{ Recovery \% } & \multirow{2}{*}{$\begin{array}{l}\text { Recovery \% } \\
\text { mean } \pm \text { SD }\end{array}$} \\
\hline & 250 (ng) & 500 (ng) & 750 (ng) & \\
\hline $\mathrm{K}^{+}$ & 99.84 & 100.01 & 100.5 & $100.11 \pm 0.34$ \\
\hline $\mathrm{Ca}^{2+}$ & 99.26 & 99.14 & 100.78 & $99.72 \pm 0.91$ \\
\hline $\mathrm{Mg}^{2+}$ & 99.57 & 100.90 & 99.40 & $99.95 \pm 0.82$ \\
\hline $\mathrm{Fe}^{2+}$ & 98.94 & 100.57 & 101.12 & $100.21 \pm 1.13$ \\
\hline $\mathrm{Co}^{2+}$ & 98.37 & 99.03 & 100.01 & $99.13 \pm 0.82$ \\
\hline Vitamin B & 98.80 & 99.60 & 99.90 & $99.43 \pm 0.56$ \\
\hline Vitamin C & 96.98 & 96.40 & 95.32 & $96.23 \pm 0.84$ \\
\hline Glucose & 99.58 & 100.04 & 101.09 & $100.23 \pm 0.77$ \\
\hline Fructose & 98.35 & 99.74 & 100.07 & $99.38 \pm 0.91$ \\
\hline Protein & 97.00 & 99.71 & 99.96 & $98.89 \pm 1.64$ \\
\hline
\end{tabular}

Table 7. Effect of diver's species on the percent recovery of $M B C$ by the proposed method $B$.

\begin{tabular}{lllll}
\hline \multirow{2}{*}{$\begin{array}{l}\text { Foreign } \\
\text { species }\end{array}$} & \multicolumn{2}{l}{ Recovery \% } & $\begin{array}{l}\text { Recovery \% } \\
\text { mean } \pm \text { SD }\end{array}$ \\
\cline { 2 - 4 } & $\mathbf{2 5 0} \mathbf{~ n g}$ & $\mathbf{5 0 0} \mathbf{~ n g}$ & $\mathbf{7 5 0} \mathbf{~ n g}$ & $99.15 \pm 0.66$ \\
$\mathrm{~K}^{+}$ & 99.83 & 99.12 & 98.50 & $99.29 \pm 0.91$ \\
$\mathrm{Ca}^{2+}$ & 98.28 & 99.57 & 100.04 & $99.24 \pm 1.33$ \\
$\mathrm{Mg}^{2+}$ & 97.85 & 99.39 & 100.50 & $99.74 \pm 1.18$ \\
$\mathrm{Fe}^{2+}$ & 99.64 & 98.61 & 100.97 & $98.29 \pm 1.21$ \\
$\mathrm{Co}^{2+}$ & 99.25 & 96.93 & 98.71 & $97.14 \pm 1.51$ \\
Vitamin B & 98.83 & 96.69 & 95.90 & $96.70 \pm 1.19$ \\
Vitamin C & 97.38 & 97.40 & 95.32 & $99.15 \pm 1.41$ \\
Glucose & 99.87 & 97.52 & 100.06 & $97.81 \pm 1.23$ \\
Fructose & 97.54 & 99.17 & 96.74 & $97.66 \pm 1.09$ \\
Protein & 99.00 & 97.33 & 96.95 &
\end{tabular}


Table 8. Analytical results of carbendazim in different samples by proposed method A.

\begin{tabular}{|c|c|c|c|c|}
\hline Sample & $\begin{array}{l}\text { MBC } \\
\text { added } \\
\left(\text { ngmL }^{-1}\right)\end{array}$ & $\begin{array}{l}\text { MBC found } \\
\text { (ng mL }{ }^{-1} \pm \text { SD) }\end{array}$ & $\begin{array}{l}\text { Recovery\% } \\
(\text { mean } \pm \text { SD) }\end{array}$ & $\begin{array}{l}\text { RSD \% } \\
\mathrm{n}=5\end{array}$ \\
\hline \multirow{3}{*}{ Tap water } & 3 & $2.98 \pm 0.04$ & $99.33 \pm 1.24$ & 1.39 \\
\hline & 7 & $6.97 \pm 0.08$ & $99.57 \pm 0.97$ & 1.16 \\
\hline & 13 & $12.86 \pm 0.10$ & $98.92 \pm 0.71$ & 0.83 \\
\hline \multirow{3}{*}{ Cucumber } & 3 & $2.85 \pm 0.07$ & $95.00 \pm 2.49$ & 2.63 \\
\hline & 7 & $7.01 \pm 0.12$ & $100.14 \pm 1.74$ & 1.84 \\
\hline & 13 & $12.76 \pm 0.15$ & $98.15 \pm 1.22$ & 1.25 \\
\hline \multirow{3}{*}{ Tomato } & 3 & $2.93 \pm 0.06$ & $97.66 \pm 2.04$ & 2.09 \\
\hline & 7 & $6.84 \pm 0.12$ & $97.71 \pm 1.70$ & 1.74 \\
\hline & 13 & $12.79 \pm 0.13$ & $98.38 \pm 0.97$ & 0.99 \\
\hline \multirow{3}{*}{ Orange } & 3 & $2.94 \pm 0.05$ & $98.00 \pm 1.79$ & 1.83 \\
\hline & 7 & $6.90 \pm 0.10$ & $98.57 \pm 1.45$ & 1.48 \\
\hline & 13 & $12.87 \pm 0.15$ & $99.00 \pm 1.13$ & 1.15 \\
\hline
\end{tabular}

Table 9. Analytical results of carbendazim in different samples by proposed method $B$.

\begin{tabular}{|c|c|c|c|c|}
\hline Sample & $\begin{array}{l}\text { MBC } \\
\text { added } \\
\left(\text { ngml }^{-1}\right)\end{array}$ & $\begin{array}{l}\text { MBC found } \\
\text { (ng mL }{ }^{-1} \pm \text { SD) }\end{array}$ & $\begin{array}{l}\text { Recovery\% } \\
(\text { mean } \pm \text { SD) }\end{array}$ & $\begin{array}{l}\text { RSD } \% \\
n=5\end{array}$ \\
\hline \multirow{3}{*}{ Tap water } & 4 & $3.93 \pm 0.05$ & $98.25 \pm 1.24$ & 1.31 \\
\hline & 10 & $9.92 \pm 0.09$ & $99.20 \pm 0.97$ & 0.95 \\
\hline & 18 & $17.87 \pm 0.15$ & $99.27 \pm 0.71$ & 0.83 \\
\hline \multirow{3}{*}{ Cucumber } & 4 & $3.86 \pm 0.08$ & $96.50 \pm 2.49$ & 2.13 \\
\hline & 10 & $9.84 \pm 0.17$ & $98.40 \pm 1.74$ & 1.72 \\
\hline & 18 & $18.01 \pm 0.19$ & $100.05 \pm 1.22$ & 1.11 \\
\hline \multirow{3}{*}{ Tomato } & 4 & $3.90 \pm 0.09$ & $97.50 \pm 2.04$ & 2.23 \\
\hline & 10 & $9.92 \pm 0.16$ & $99.20 \pm 1.70$ & 1.63 \\
\hline & 18 & $17.95 \pm 0.16$ & $99.72 \pm 0.97$ & 0.91 \\
\hline \multirow{3}{*}{ Orange } & 4 & $3.99 \pm 0.06$ & $99.75 \pm 1.79$ & 1.55 \\
\hline & 10 & $10.05 \pm 0.12$ & $100.50 \pm 1.45$ & 1.18 \\
\hline & 18 & $17.84 \pm 0.15$ & $99.11 \pm 1.13$ & 0.82 \\
\hline
\end{tabular}

Table 10. Statistical comparism between Method $A$ and $B$ for the determination of $M B C$ in real samples by CPE- spectrophotometry.

\begin{tabular}{|c|c|c|c|c|}
\hline Method A & Method B & $\begin{array}{l}\text { Statistical } \\
\text { Parameters }\end{array}$ & Method A & Method B \\
\hline 99.33 & 98.25 & Mean & 98.38583 & 98.97083 \\
\hline 99.57 & 99.20 & Variance & 1.680808 & 1.304608 \\
\hline 98.92 & 99.27 & Observations & 12 & 12 \\
\hline 95.00 & 96.50 & Pooled Variance & 1.492708 & \\
\hline 100.14 & 98.40 & dof & 22 & \\
\hline 98.15 & 100.05 & t Stat & -1.17285 & \\
\hline 97.66 & 97.50 & $\mathrm{P}(\mathrm{T}<=\mathrm{t})$ one-tail & 0.126699 & \\
\hline 97.91 & 99.20 & $\begin{array}{l}\text { t Critical } \\
\text { one-tail }\end{array}$ & 1.717144 & \\
\hline 98.38 & 99.72 & $\mathrm{P}(\mathrm{T}<=\mathrm{t})$ two-tail & 0.253398 & \\
\hline 98.00 & 99.95 & $\begin{array}{l}\text { t Critical } \\
\text { two-tail }\end{array}$ & 2.073873 & \\
\hline 98.57 & 100.5 & F Stat & 1.288 & \\
\hline 99.00 & 99.11 & $F_{\text {crit, }}$ dof $=11$ & 2.81 & \\
\hline
\end{tabular}

\section{Conclusion}

This work accentuates the established methods based on designed two CPE procedures before spectrophotometric analysis for the determination of ultra trace carbendazim residues in a variety of samples. Despite various analytical methods reported in a chemical literature for the detection of $\mathrm{MBC}$ in different samples, to our knowledge this is the first CPE-spectrophotometry for MBC depended on the reaction of the target analyte with the well-known reaction system reported in a scientific literature. The proposed methods provide good analytical features such as a linear range, limit of detection, accuracy, precision and interferences-free, which can be applicable for routine quantitative analysis in the quality control laboratories for $\mathrm{MBC}$ in the environmental samples, due to the simplicity, rapidity, inexpensive and eco-friendly.

\section{Acknowledgement}

The authors gratefully thank the Ministry of Education, Baghdad, Iraq for the provision of a grant to Suher S. Ahmad for M.Sc study.

\section{References}

[1] Venetian A, Vacca, G, Arana S, De Simone F and L. Rastrelli (2004) Determination of carbendazim, thiabendazole and thiophanate-methyl in banana (Musa acuminata) samples imported to Italy. Food Chem 87: 383-386.

[2] Tomlin C Ed. (1994) The Pesticide Manual, 10th ed. British Crop Protection Council and Royal Society of Chemistry, U.K., p. $149-50$

[3] Mazo LH, Coutinho CF, Galli A. and Machado SAS (2006) Carbendazim EO meio ambiente: degradação e toxidez. Pesticidas (UFPR), v. 16, p. 63-70.

[4] Olayemi OA (2015). Comparative toxicity of two different pesticides on the skin of Japanese quail (Cortunix japonica). World Vet J 5: 13-18.

[5] European Communities; Council Directive 98/83/EC on the Quality of Water Intended for Human Consumption L 330/32; Official Journal of the European Communities: Brussels, December (1998).

[6] United States Environmental Protection Agency (US EPA); Drinking Water Contaminants; U.S. Agency for International Development: Washington D.C. May (2009).

[7] Codex Alimentarius Commission. Pesticides residue in food. Joint FAO/ WHO Food Standard Programme of United Nations. Vol. 2, $2^{\text {nd }}$ ed. Rome. (1993).

[8] GB 14870-1994: Maximum Residue Limits of Carbendazim in Foods; Standardization Administration of China (SAC), General Administration of Quality Supervision, Inspection and Quarantine of the People's Republic of China: Beijing (1994).

[9] ANVISA, Agencia Nacional de Vigilancia Sanitaria, Public Consultation No. 113 of December 19th, (2007).

[10] Bushway RJ, Hurst HL, Kagabalasooriar J, and Perkins LB (1991) Determination of carbendazim in blueberries by reversed phase high-performance liquid chromatography. J Chromatogr 587: 321-24. 
[11] Regis-rolle SD and Bauville GM (1993) High-performance liquid chromatographic method for the determination of carbendazim residues in crops, grains, and wines with fluorescent detection. Pestic Sci 37: 273-82.

[12] Phansawan B, Prapamonto T, Thavornyutikarn P, Chantara S, Mangklabruks A and C. Santasup C (2015) A Sensitive method for determination of carbendazim residue in vegetable samples using HPLC-UV and its application in health risk assessment. Chiang Mai J Sci 42: 681-690.

[13] Thomas DH, Lopez-Avila V, Betowski LD and Van Emon J (1996) Determination of carbendazim in water by high-performance immunoaffinity chromatography on-line with high-performance liquid chromatography with diode-array or mass spectrometric detection. J Chromatogr A 724: 207-217.

[14] Vega BA, Frenich GA and Vidal MLJ (2005) Monitaring of pesticides in agricultural water, soil samples from Andalusia by liquid chromatography coupled to mass spectrometry. Anal Chim. Acta 538: 117-127.

[15] Cheng P, Tang HM, Yang SX and L. Wang L (2009) Determination of carbendazim residue in tomato and cucumber by HPLC-MS-MS. Modern Agrochemicals 3: 36-37.

[16] Steinwandter H (1985) Chemical derivatization in residue analysis in gas chromatographic determination of carbendazim after alkylation with diazomethane and diazoethane. Fresenius' Z Anal Chem 321: 599-600.

[17] Subhani Q, Huang Z. Zhu Z. and Zhu Y (2013) Simultaneous determination of imidacloprid and carbendazim in water samples by ion chromatography with fluorescence detector and post-column photochemical reactor. Talanta 116: 127-132.

[18] Ashrafi AM, Đorđević J, Guzsvány V, Švancara I, Trtić-Petrović T, Purenović M and Vytřas K (2012) Trace determination of carbendazim fungicide using adsorptive stripping voltammetry with a carbon paste electrode containing tricresyl phosphate. Int J Electrochem Sci 7: 9717-9731.

[19] Manisankar P, Selvanathan G and Vedhió C (2005) Utilisation of polypyrrole modified electrode for the determination of pesticides. Int J Environ Anal Chem 85: 409-422.

[20] Li Jand Chi Y (2009) Determination of carbendazim with multiwalled carbon nanotubes-polymeric methyl red film modified electrode. Pesticide Biochem Physiol 93: 101-104.

[21] Ribeiro WF, Selva TMG, Lopes IC, Coelho ECS, Lemos SG, de Abreu FC, do Nascimento VB and de Araujo MCU (2011) Electroanalytical determination of carbendazim by square waveadsorptive stripping voltammetry with a multiwalled carbon nanotubes modified electrode. Anal Methods 3: 1202-1206.

[22] Itak JA, Selisker MY, Jourdan SW, Fleeker JR and Herzogt DP (1993) Determination of benomyl (as carbendazim) and carbendazim in water, soil, and fruit juice by a magnetic particle-based immunoassay. J Agric Food Chem 41: 2329-2332.

[23] Zhu HS, Wu LH, Li RB, Xia LA, Han JQ, Zhang QJ, Bian YC and Yu QR (2008) Determination of pesticides in honey using excitation - emission matrix fluorescence coupled with second - order calibration and second - order addition methods. Anal Chim Acta 619: 165-172.

[24] Naidu KP, Niranjan $T$ and Naidu VS (2011) Spectrophotometric determination of carbendazim in its formulations and environmental samples. Intern $\mathrm{J}$ ChemTech Res 3: 1728-1733.

[25] Wu YS and Lee HK (1997) Determination of carbendazim residues in grains by solid-phase extraction and micellar electrokinetic chromatography with ultraviolet detection. J Chromatogr Sci 35: 513-518.

[26] Ebaisat H (2011) Determination of some benzimidazole fungicides in tomato puree by high performance liquid chromatography with SampliQ polymer SCX solid phase extraction. Arab J Chem 4: 115-117.

[27] Kong HX, Yun H and Qiu NX (2007) Determination of carbendazim residue in apple juice concentrate by high performance liquid chromatography with solid-phase extraction. Chin J Anal Lab 26: 65-67.

[28] Michel M and Buszewski B (2004) Optimization of a matrix solid-phase dispersion method for the determination analysis of carbendazim residue in plant material. J Chromatogr B 800: 309-314.

[29] Hu Y Yang X, Wang Z, Wang C and Zhao J (2005) Determination of carbendazim and thiabendazole intomatoes by solid-phase microextraction coupled with high performance liquid chromatography and fluorescence detection. Chin J Chromatogr 23: 581-584.

[30] Wu Q, Li Y, Wang C, Liu Z, Zang Z, Zhou X and Wang Z (2009) Dispersive liquid liquid microextraction combined with high performance liquid chromatography-fluorescence detection for the determination of carbendazim and thiabendazole in environmental samples. Anal Chim Acta 638: 139-145.

[31] Pourreza N, Rastegarzadeh S and Larki A (2015) Determination of fungicide carbendazim in water and soil samples using dispersive liquid-liquid microextraction and microvolume UV-Vis spectrometry. Talanta 134: 24-29.

[32] Asensio-Ramos M, Hernández-Borges J, Borges-Miquel, TM and Rodríguez-Delgado A (2011) Ionic liquid-dispersive liquid-liquid microextraction for the simultaneous determination of pesticides and metabolites in soils using high-performance liquid chromatography and fluorescence detection. J Chromatogr A 1218: 4808-4816.

[33] Zhou ZM, Chen JB, Zhao DY and Yang MM (2009) Determination of four carbamate pesticides in corn by Ccoud point extraction and high-performance liquid chromatography in the visible region based on their derivatization reaction. $\mathrm{J}$ Agr Food Chem 57: 8722-8727.

[34] Tang T, Qian K, Shi T, Wang F, Li J, and Cao Y (2010) Determination of triazolefungicides in environmental water samples by high performance liquidchromatography with cloud point extraction using polyethylene glycol 600 monooleate. Anal Chim Acta 80: 26-31.

[35] Chen JB, Zhao WJ, Liu W, Zhou ZM and Yang MM (2009) Cloud point extraction coupled with derivative of carbofuran as a preconcentration step prior to HPLC.Food Chem 115: 10381041.

[36] Melchert WR and Rocha FRP (2009) Cloud point extraction and concentration of carbaryl from natural waters. Intern $\mathbf{J}$ Environ Anal Chem 89: 969-979.

[37] Khammas ZAA and Ahmad SS. (2016) Micelle-mediating extraction combined with visible spectrophotometry for the determination of ultra trace amounts of bendiocarb insecticide in various matrices after oxidative coupling with O-Toluidine. Int Res J Pure Appl Chem 10: 1-16. 
[38] Schenck FJ and Hobbs JE (2004) Evaluation of the quick, easy, cheap, effective, rugged, and safe (QuEChERS) approach to pesticide residue analysis. Bull Environ Contamint and Toxicol 73: $24-30$.

[39] Theis TL and Singer PC (1973) the stabilization of ferrous iron by organic compounds in natural water, In P. C. Singer [ed.], Trace metals and metal-organic interactions in natural waters. Ann Arbor Sci. p. 303-320.

[40] Theis TL and Singer PC (1973) Complexation of iron (II) by organic matter and its effect on iron (II) oxygenation. Enviro. Sci Technol 8: 569-573.

[41] Stumm W and Lee GF. (1960) The chemistry of aqueous iron. Schweiz Z Hydrol 22: 295-319.

[42] Mohammed AA, Talaat E, Mohamed, Y and Shama SA (2012) Application of oxidants to the spectrophotometric microdetermination of meclizine $\mathrm{HCl}$ in pure and pharmaceutical formulations. Prime J Microbiol Res 2: 137-140. 